\title{
Development of Methodology and Assessment of Ecological Safety of the EAEU and CIS Regions in the Context of Sustainable Development
}

\author{
Svetlana Demidova ${ }^{1, *(1)}$, Michael Balog ${ }^{2}{ }^{\oplus}$, Tatiana Chircova ${ }^{2} \oplus$, Anastasia Kulachinskaya ${ }^{3}\left(\mathbb{D}\right.$, Svetlana Zueva $^{4}$, \\ Irina Akhmetova ${ }^{5}$ and Svetlana Ilyashenko ${ }^{6}$ \\ 1 Department of Public Finance, Financial University, 125993 Moscow, Russia \\ 2 Institute of Law, Economics and Management, Pskov State University, 180000 Pskov, Russia; \\ seb5658@yandex.ru (M.B.); chircovatatiana@gmail.com (T.C.) \\ 3 Graduate School of Industrial Economics, Peter the Great St. Petersburg Polytechnic University, \\ 195251 St. Petersburg, Russia; a.kulachinskaya@yandex.ru \\ 4 Department of Industrial Engineering, Information and Economy, University of L'Aquila, 67100 L'Aquila, \\ Italy; svetlanaborisovna.zueva@univaq.it \\ 5 Department of Economics and Organization of Production, Kazan State Power Engineering University, \\ 420066 Kazan, Russia; irina_akhmetova@mail.ru \\ 6 Base Chair of the Trade Policy, Plekhanov Russian University of Economics, 115093 Moscow, Russia; \\ Ilyashenko.sb@rea.ru \\ * Correspondence: demidovapsk@gmail.com
}

Citation: Demidova, Svetlana, Michael Balog, Tatiana Chircova, Anastasia Kulachinskaya, Svetlana Zueva, Irina Akhmetova, and Svetlana Ilyashenko. 2021.

Development of Methodology and Assessment of Ecological Safety of the EAEU and CIS Regions in the Context of Sustainable Development. Economies 9: 100. https://doi.org/ 10.3390/economies 9030100

Academic Editor: George Halkos

Received: 13 April 2021

Accepted: 18 June 2021

Published: 1 July 2021

Publisher's Note: MDPI stays neutral with regard to jurisdictional claims in published maps and institutional affiliations.

Copyright: (c) 2021 by the authors. Licensee MDPI, Basel, Switzerland. This article is an open access article distributed under the terms and conditions of the Creative Commons Attribution (CC BY) license (https:// creativecommons.org/licenses/by/ $4.0 /)$.

\begin{abstract}
The trends of sustainable development and green agenda transform the production processes, leading industries, and regional markets, and reveal objective contradictions in ensuring the ecological safety of certain territories. This study aims to develop a methodology and assess ecological safety at aggregated system levels, taking into account natural and socioeconomic factors as well as the factor of human capital development with specification of the place of ecological safety in the concept of sustainable development. The objects of empirical research are the EAEU and CIS countries for the period 2010-2019, as well as 85 Russian regions. The scientific research toolkit is based on the methods of structural-logical, economical-statistical, and comparative analyses, and expert judgments. The concepts of sustainable development and human capital and the theory of the national school of ecological safety are analyzed using the systematic approach. The mixed methodological approach showed the interconnection of four approaches of assessing ecological safety (technogenic, environmental, institutional, resource-based). The authors developed a method for assessing ecological safety taking into account the contribution of human capital. The assessment results are typologized and grouped according to the dynamic trend. For the majority of the considered countries, changes in the level of ecological safety correlate with changes in socioeconomic indicators. The same trend is observed when considering the Russian regional formations. The contribution of human capital was recorded to a lesser extent. For several regions, the increased number of objects polluting the environment is accompanied by a decreased volume of polluting emissions into the atmosphere.
\end{abstract}

Keywords: ecological safety; environment; sustainable development; environmental policy; green economy; human capital; circular economy

\section{Introduction}

The concept of sustainable development (SD) began to develop in eighteenth-century Europe (Mieg and Töpfer 2015). This topic has been actively discussed since the 1970s against the background of the aggravated environmental problems. Sustainable development was defined by the UN Brundtland Commission as "development that meets the needs of the present without compromising the ability of future generations to meet their 
own needs" (World Commission on Environment and Development 1987) ${ }^{1}$ This approach has received a lot of criticism. It does not consider specifications of needs and ways to meet them (Danilov-Danil'yan 2015). The ethical issue of obligations towards descendants is disputed. Since we do not know all the consequences of our actions, we cannot discuss the possible harm to future generations (Mieg and Töpfer 2015). Sustainable development is also considered an ideology that ignores negative environmental changes and socioeconomic inequality (Fuchs 2017). The UN Sustainability Concept considers nature only as a resource to meet human needs (Skene 2020).

One of the reasons for multiple debates on SD is the absence of a joint knowledge management strategy among UN member states (Ricardo 2021). The essence of sustainable development is considered in various theoretical approaches. These include the knowledgebased and the process-oriented approaches. The knowledge-based approach involves the creation of universal definitions of SD based on objective information. The process-oriented approach formulates definitions to address the specific sustainability issues based on the local context, knowledge, and values of the subjects involved (Miller 2013). If these two approaches are not strongly linked, there is a risk of not taking into account the fundamental principles of sustainable development or lose the involvement of local communities in this process (Hedelin 2019).

Sustainable development can be understood using the following three approaches. The weak substitutability postulates the replaceability of a natural ecosystem with products of technological progress and determines the priority of human interests over the interests of nature. Strong sustainability emphasizes the importance of balancing the interests of the environment and humanity based on the ideas of the irreplaceability of natural capital and limited resources. Absurdly strong sustainability is a system of radical views that prohibit the exploitation of ecosystems and proposes to restore the environment by stopping human development. Strong sustainability is a strategic priority, but weak sustainability is more widespread in global practice due to imbalances in socioeconomic development and different levels of environmental culture (Shi et al. 2019).

Production-consumer, natural science, and integrated approaches to sustainable development are also being discussed in scientific literature. The production-consumer approach limits the concept of sustainable development by creating favorable conditions for economic growth and improving life quality, thereby defining the natural environment as a secondary object that has no independent value (Sugak 2019). The natural science approach considers sustainable development in the context of the limitations of anthropogenic impact on the biosphere. The integrated approach considers development without destruction of the natural basis of society, while the living conditions being created do not entail human degradation (Danilov-Danil'yan 2015).

The formulation of the UN Sustainable Development Goals has become a step forward in improving welfare and protecting the environment. However, skeptics draw attention to serious problems in achieving the set goals. Within the framework of the existing model of economic development, the eradication of poverty by bringing the income of those in need up to $\$ 5$ a day will require an increase in world GDP by 175 times, which is a fantastic scenario (Hickel 2015). The implementation of the Sustainable Development Goals will be limited by the lack of the necessary global resources (Eskelinen 2021). Hedelin discusses the contradictions of the set goals (Hedelin 2019). It is noted that to achieve sustainable development, humanity should abandon the optimization of the conditions for its success (Skene 2020). Collaboration of natural and social scientists with other concerned parties is also required (Mieg and Töpfer 2015).

The paradigm of sustainability includes concepts of national science schools. One of them is the concept of ecological safety, which is addressed by Russian scientists. It is rarely discussed in international documents and studies and is mainly associated with technical solutions in the field of labor protection, medicine, energy, chemical, and food industries (Liu et al. 2020). The world theory and practice consider the issues of environmental 
protection and human well-being within the framework of the sustainability paradigm, the core of which is the concept of sustainable development.

The Russian scientists consider various interpretations of ecological safety (Polyanskaya and Yurak 2017; Demidova 2018; Pisarenko et al. 2019; Abanina et al. 2019; Gutman and Teslya 2018). They have common grounds that bring the views of most authors together. The first ground is a similar understanding of threats to ecological safety in the form of natural, anthropogenic, and man-made adverse impacts. The second is its goal, which consists of protection of the environment, population, and business. Some scientists, considering a man and the results of his activities as an object of ensuring ecological safety, leave without due attention natural areas with natural inhabitants. The practical implementation of this idea is the presence of significant control zones in Russia. Control zones are areas where forest fires can be left without suppressing if the projected costs exceed the projected damage. So, in the northern part of Russia forest fires occupy large territories, this results in permafrost melting, thereby driving climate change and infrastructure destruction ${ }^{2}$.

Several conclusions can be drawn while comparing the concepts of sustainable development and ecological safety. Firstly, in many interpretations, these concepts are substantially similar as they consider the natural and social components of the surrounding world as equivalent objects. Various concepts are used by scientists to convey to the whole world the need to harmonize the interests of mankind and nature. Secondly, a significant difference between these two concepts is the scale of goals formulated by the scientists. Ecological safety is focused on achieving protection of certain objects from various threats, which follows from the semantics of the term safety. At the same time, sustainable development has more ambitious goals, since it is focused on the process of all-encompassing qualitative changes, improving the surrounding world. Based on this difference in the content of concepts, we consider ecological safety as a basic component of sustainable development (Appendix A, Figure A1). Ecological safety and sustainable development depend on the successful implementation of complementary environmental, economic and human capital policies.

To achieve sustainable development goals one should regularly monitor the statistic data and assess the implementation of sustainability policies at the level of countries and regions. Studies show that European countries differ significantly in the achieved level of sustainable development. The countries in Western and Northern Europe have the highest rates, while those in Southern and Eastern Europe show worse results (Kiselakova et al. 2020). The EU countries demonstrate strong positive shifts in ecological issues (even with a lag in the socioeconomic sphere) due to reduction of greenhouse gas emissions and primary energy consumption (Urbaniec 2016). In Europe, the high efficiency of the implementation of sustainable development policies is achieved by environmental protection dictated by ecological culture and economic considerations (Lozowicka 2020). In the cities of South Korea, China, Germany, and Sweden the sustainable urban development is primarily associated with technical solutions in the field of environment and, to a lesser extent, with the solution of social issues. The issue of keeping low housing prices in eco-cities is the most worrisome (Medved et al. 2020). In the countries of Central Asia, only the environmental component of the SD goals is developed enough (Huan et al. 2019). In China, positive environmental changes are associated with technological progress despite the low environmental efficiency of most large cities, the majority of which are socially and economically developed (Long 2021). The rapid economic development of India is accompanied by serious environmental problems-only less than one percent of the country's population breathes air that meets the global WHO guidelines for pollution levels (Purohit et al. 2019). A study of Indonesia's regions has shown that high economic growth and good environmental quality are not always associated with high levels of sustainable development (Rahma et al. 2019). The example of Taiwan clearly shows that representatives of the public and private sectors pay great attention to the economic 
component of sustainable development. In contrast, for nonprofits, the environmental and social components are more relevant (Ma and Chang 2019).

Empirical research shows that progress in sustainable development strongly depends on the country and its sustainability scores. Moreover, the attention of scientists is unevenly distributed between different territories. This situation motivates us to study the ecological component of SD since it is the most controversial. It isn't well studied on the territory of the EAEU and CIS countries. Thus, this study solves the problem of insufficient attention to assessing ecological safety as a basic component of SD in these territories. Ecological safety is described by three blocks of indicators. The first block assesses the level of socioeconomic development of the territory, the second assesses the ecological state, the third assesses the human potential.

This work aims to develop a methodology and assess ecological safety at aggregated system levels. The presented approach takes into account natural, socioeconomic factors, and the human capital factor, and specifies the place of ecological safety in the concept of sustainable development. The objects of the study are the countries of the EAEU and the CIS for the period 2010-2019, as well as the subjects of Russia (85 regional units).

\section{Approaches to the Study of Ecological Safety of Regions}

Ecological safety and environmental safety are studied using various methods, systems of indicators, and tools.

Sustainability (the ability of territory to cope with health inequalities) and vulnerability of environmental health (showing the cumulative harmful effects to which the population is exposed) were studied based on the cross-interpretation of spatial composite indices related to economic, environmental, political, medical, service, and social aspects using the example of French municipalities (Brousmiche et al. 2021).

The impact of urbanization on ecological safety was considered by (Abanina et al. 2019; Liu et al. 2020). The model of ecological development of an urbanized territory (developed on the example of the Russian region) is focused on the development of natural, social, ecological factors of development and the anthropogenic factor of territories (Abanina et al. 2019). The authors associate ecological safety with compliance with environmental standards.

The environmental effects of urban expansion were quantified using the example of Chinese regions. The results obtained help to optimize future urban development, develop an environmental management strategy and promote sustainable urban development, taking into account the economy, society, and the environment (Liu et al. 2020; Zhang et al. 2021). The improvement of rural industrial lands' planning was concluded to be important for achieving the SD goals.

Ecological safety in industrial regions is considered in (Rodnyansky et al. 2020; Ganebnykh et al. 2019) The direct relationship between the number of industrial enterprises and ecological safety is confirmed in (Ganebnykh et al. 2019) based on the perception map. The necessity of introducing green technologies was noted, however, this direction was not analyzed.

The public administration in the field of ecological safety is assessed by the number of investment volumes, employment, and the placement of environmental services in industrial regions (Rodnyansky et al. 2020).

A comprehensive methodology for assessing the ecological safety of territory was proposed in (Glinskiy et al. 2015). The authors introduced a consolidated index of ecological safety through the aggregation of three indicators describing the socioeconomic development, ecological situation, and human potential of the region.

A qualitatively new tool--neural network models-was used to analyze and forecast the social and environmental risks for industrial regions (Sugak 2019). Experimental calculations were carried out in Krasnoyarsk and Krasnoyarsk Territory. Studies (Druzhinin et al. 2018; Morozova and Debelaya 2018; Wendling et al. 2020; Nikulina 2014) were also analyzed. 
The analyzed methods have the following main limitations:

- Too many indicators are used, there is no clear definition of environmental sustainability;

- They are focused on assessing the anthropogenic load of the territory;

- Some of them have a small list of indicators and the complexity of collecting information;

- The individual groups of indicators are assessed too difficult;

- They do not have available initial information;

- Sometimes assessment is carried out only from the standpoint of the ecosystem ability to restore;

- Statistical observation of several indicators is carried out only at the municipal level.

- The considered studies were mainly focused on individual economically significant large and medium-sized cities or ecologically disadvantaged areas. Larger research areas such as urban areas, regions, or provinces have been studied less frequently (Liu et al. 2020).

Each region (territory) has specific characteristics of natural, economic, social, and other conditions of functioning, and the issue of developing a comprehensive methodology for assessing ecological safety remains open.

\section{Ecological Safety of Enterprises as a Factor of Regional Environmental Sustainability}

The main violation of the ecological safety of the regions is made by production facilities. From the point of view of ensuring ecological safety, the sustainable development of any industrial enterprise is understood as a set of measures aimed at reducing the negative impact of the enterprise's activities on the components of the natural environment through compliance with the requirements of environmental legislation, and eliminating the negative consequences of the impact of anthropogenic factors on the environment (Vahrushev 2015).

International requirements for enterprise management in the field of ecology are presented in ISO 14000 standard. This international standard contains the requirements for the environmental management system, according to which certification is passed. However, in the Russian Federation, this standard is not mandatory, and its analogue is the law "On environmental protection" (N 7-FZ) and the national standard GOST R ISO 14000. The latter says that ecological safety at the enterprise should be achieved through the introduction of effective environmental management.

The measures to ensure ecological safety at various production facilities cannot and should not be identical in the Russian Federation. However, until 2013, environmental protection requirements were the same for everyone. The situation has changed with the introduction of the classification of hazardous production facilities according to their negative impact on the environment (Figure 1). It should be noted that the developed classification is unified with the EU legislation. ${ }^{3}$

The main component of ensuring the ecological safety of enterprises is industrial environmental control. It ensures the fulfillment of environmental protection requirements in the process of enterprises' activities. The objects of the IV category do not obey it. The objects of the I-IV categories must develop and implement a program of industrial environmental control following the established requirements.

Also, from 1 January 2019, after the entry into force of the national environmental management standard, industrial facilities of the I category must obtain an integrated environmental permit (IEP). It is a document containing mandatory requirements for environmental protection. Enterprises of the II hazardous category should receive an IEP or are obliged to submit a declaration on the impact on the environment.

One of the effective mechanisms to reduce the enterprise adverse impact is to limit the number of harmful substances allowed for emission or discharge. According to the legislation of the Russian Federation, the standards for maximum permissible emissions are necessarily established for enterprises of categories I and II. 


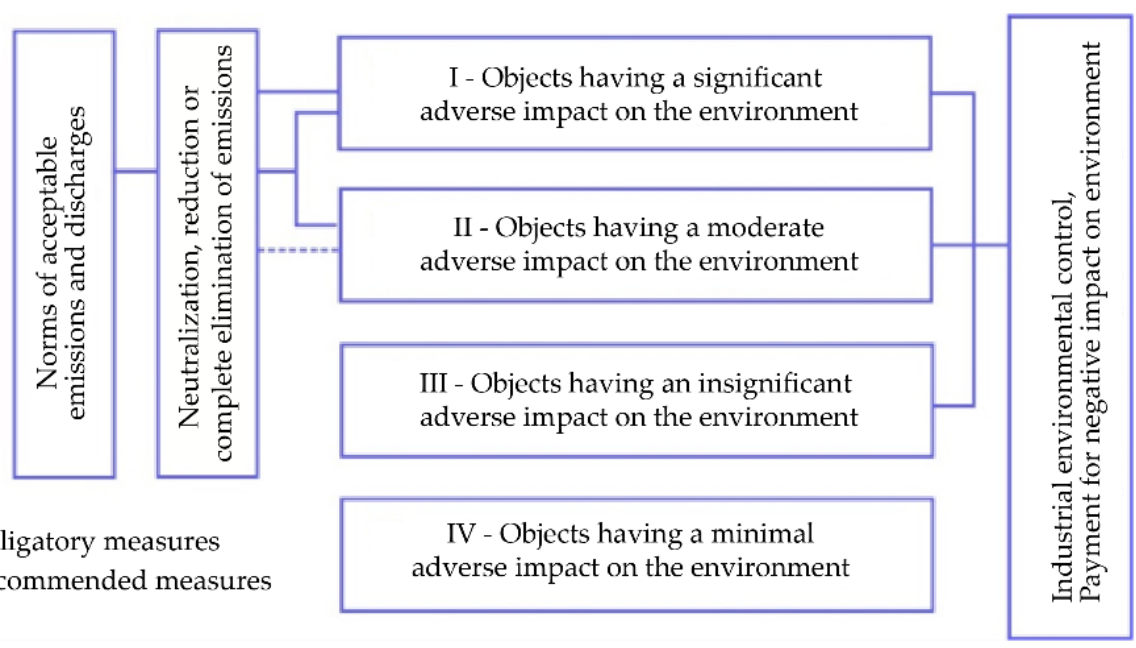

Figure 1. Classification of hazardous production facilities and methods of environmental control.

Legal entities and individual entrepreneurs are in charge of any negative impact on the environment, i.e., emissions and discharges of pollutants, and waste disposal. The only exceptions are enterprises operating at facilities of the IV category.

To ensure sustainable development, any enterprise should be guided by socioecological and economic principles (Figure 2).

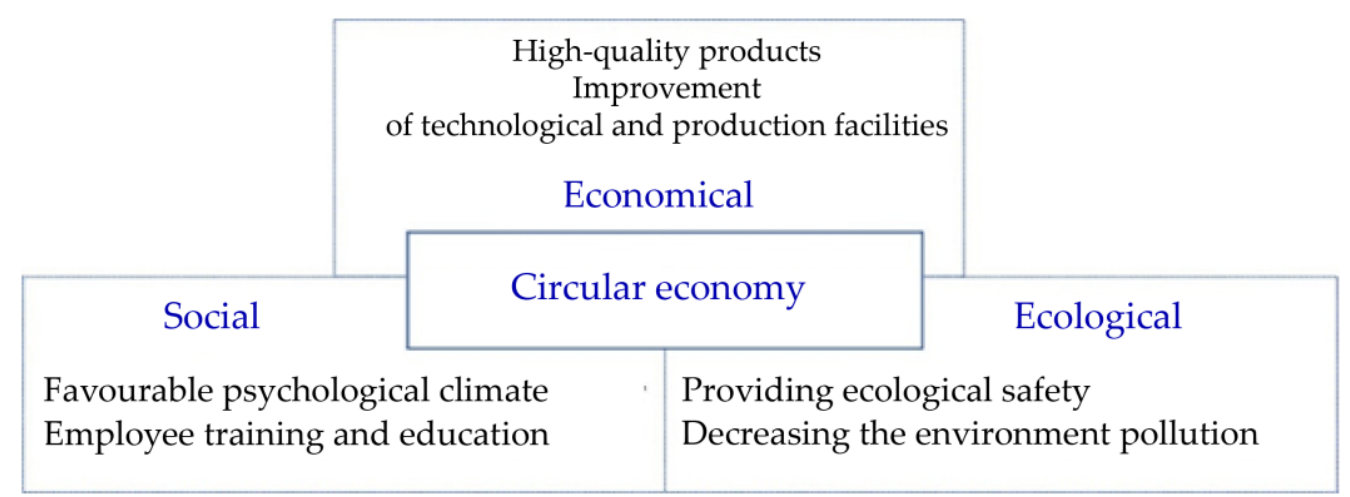

Figure 2. The principles of sustainable development of an enterprise.

Nowadays the world pays special attention to the circular economy. It is based on resource renewal, minimization of secondary raw materials, and switching from fossil fuels to renewable energy sources. At some enterprises, zero waste technologies are introduced, or waste of one company becomes a raw material for the other one. Most EU countries introduce tax breaks for those who use renewable energy sources.

Circular economy eliminates the possibility of waste generation even at the design stage, while simultaneously saving production, human, social, natural, and financial capital. The economic benefit from the transition to this model in Europe by 2030 is estimated at $€ 1.8$ trillion (De Buaredon 2017). In addition to creating jobs and improving the wellbeing of the population, the transition provides an excellent opportunity to protect the environment.

The level of recycling of solid municipal waste in the Russian Federation, according to data for 2015, was only $8 \%$, while in Germany about $99 \%$ is recycled (Pahomova et al. 2017). In 2019, a reform of waste management has started in the Russian Federation. However, the level of waste recycling does not exceed $7 \%$, and over $90 \%$ of waste is still sent to landfills. With a $1-2 \%$ annual growth in the volume of solid municipal waste, the waste recycling capacity will be exhausted by 2024 in 32 regions, and by 2022 in 17 of them ${ }^{4}$. 
To improve the situation qualitatively, serious changes and targeted government support are needed. The development of a circular economy will open up broad prospects for the sustainable development of enterprises and regions in general and will improve the indicators of the natural environment.

\section{Methodology}

The methods are grouped based on the following four conceptual approaches to assess the ecological safety of a country or region:

- Technogenic, which considers the level of technogenic load of the territory (the state of the region's environment is associated with the need to ensure the economic growth of the territory and natural population growth);

- Ecological, which determines the eco-capacity of the territory (through the assessment of the anthropogenic impact on the environment and public health);

- Institutional, which considers the volume of green investment, employment, and the placement of environmental services;

- Resource-based, which considers the level of resource and ecological safety, resource conservation, and restoration in the region.

So, it is almost impossible to compare the results of different approaches to assess the ecological safety of a set of objects.

The proposed approach aims at assessing the level of ecological safety of a country/region and its grouping. The indicator system is formed based on the works (Druzhinin et al. 2018; Morozova and Debelaya 2018; Wendling et al. 2020; Nikulina 2014; Glinskiy et al. 2014) and others discussed earlier.

The system of indicators for assessing the ecological safety of regions is formed using a mixed approach, which integrates the four previously discussed concepts. The integral indicator of ecological safety of territory is formed from three blocks of indicators. The first block assesses the level of socioeconomic development of the territory in terms of its economic development, the degree of accessibility of health care and education services. The second assesses the ecological state in terms of anthropogenic impact and costs aimed at restoring the natural environment. The third assesses human potential in relation to demographic situation and the number of students at various levels of the educational system.

When forming the system of indicators for each block, the availability of information on the websites of national statistical agencies or territorial statistical bodies, measurability, comparability and reliability of information were taken into account.

The developed integral indicator of ecological safety can be used to compare different regions, correct the development strategy, and predict the ecological state of the territory. The method of the adjusted multivariate average was used to level the difference in measurement units of the initial indicators, which ensured the comparability of the calculation results.

The methodological approaches presented in the literature were improved. For a more comprehensive assessment of the level of the socioeconomic situation of the region, the list of indicators of technogenic assessment of ecological safety (as a baseline) was complemented by GRP per capita, industrial production index, and investment per capita. A list of indicators has been formed that characterizes not only anthropogenic impact on the environment, but also measures aimed at leveling this impact (the share of captured and neutralized air pollutants in the total amount of waste pollutants from stationary sources; the volume of recycled and consistently used water).

The system of indicators for assessing the ecological safety of the territory:

(1) Indicators characterizing the socioeconomic development of the territory: Number of educational institutions of higher education and scientific organizations; morbidity per 1000 people; number of sports facilities; commissioning of residential buildings; commissioning of capacities of general education and preschool educational organizations; commissioning the capacity of outpatient polyclinic organizations; the 
number of doctors of all specialties; the capacity of outpatient polyclinic organizations; the number of organizations that carry out educational activities in educational programs of preschool education, childcare and supervision; organizations that carry out educational activities in educational programs of primary, basic and secondary general education; GRP per capita; investments in fixed assets per capita; share of unprofitable organizations; accounts payable of organizations; accounts receivable of organizations; industrial production index;

(2) Indicators of anthropogenic impact on the environment: Emissions of pollutants into the atmosphere from stationary sources; the share of captured and neutralized air pollutants in the total amount of effluent pollutants from stationary sources; the volume of recycled and consistently used water; discharge of contaminated waste water into surface water bodies; environmental protection costs;

(3) Indicators characterizing the level of human development: General birth rates; general mortality rates; the number of pupils in preschool educational organizations, child minding; the number of students enrolled in programs for the preparation of skilled workers, office workers; the number of students enrolled in undergraduate, specialist, and graduate programs per 10,000 people.

The system of indicators for assessing the ecological safety of the country includes:

(1) Indicators characterizing the socioeconomic development of the territory: GDP per capita, US dollars; consumer price index; industrial production index; investments in fixed assets, million US dollars; commissioning of residential buildings (all sources of financing); unemployment rate, \%; number of doctors per 10,000 people; number of preschool education institutions; number of institutions of general secondary education; number of institutions of higher education; number of hospital beds per 10,000 people; respiratory diseases, ths. diseases; diseases of the circulatory system, ths. diseases; infectious diseases, ths. diseases;

(2) Indicators of anthropogenic impact on the environment: Emissions of pollutants into the air from stationary sources, million tons; discharge of polluted wastewater, million cubic meters; area of specially protected natural zones, million hectares; investments in the main capital for environmental protection, million US dollars; production and consumption wastes, million tons; total expenditures for environmental protection, million US dollars; captured and neutralized air pollutants from stationary sources, $\%$;

(3) Indicators characterizing the level of human development: Life expectancy at birth; fertility rate; mortality rate; number of children in preschool educational institutions; number of students in daytime educational institutions; number of students of bachelor's, specialist's, master's programs: total, ths. people.

The use of these indicators in the methodology contributes to the achievement of the goal of the empirical part of the study-assessment of environmental safety at aggregated system levels, taking into account natural, socioeconomic factors and the human capital factor. Natural factors are determined by a block of indicators of anthropogenic impact on the environment. Socioeconomic factors and factors of human capital development are taken into account by blocks of indicators with the corresponding name. Thus, the level of ecological safety of the region is integrated into a generalizing indicator based on assessment of the socioeconomic development of the territory, the development of human potential and the ecological state. The initial data is a set of indicators with different measurement units. The procedure for normalizing or standardizing indicators was applied according to the formula:

$$
Y_{i j}^{n o r m}=\frac{Y_{i j}}{\max Y_{i j}}
$$

where $Y_{i j}^{\text {norm }}$ is the normalized value of the $j$-th feature possessed by the $i$-th region; $Y_{i j}$ is the actual value of the $j$-th feature for the $i$-th region. 
Further, using the formula for multidimensional average, calculated are the intermediate indicators for each block separately, and generalizing integral index of the level of ecological safety of the territory $\left(I_{\mathrm{ES}}\right)$.

$$
I_{\mathrm{ES}}=\frac{\sum_{i=1}^{n} Y_{j}^{\text {norm }}}{n}
$$

where $Y_{j}^{n o r m}$ is the normalized value of the $j$-th feature; $n$ is the number of features.

Since the indicators of each block were normalized according to the maximum value, the multivariate average was in the range from 0 to 1.

The initial database is formed by the official data of Rosstat for all constituent entities of the Russian Federation (RF) for 2014 and $2018^{5}$, as well as data from the Interstate statistical committee of the commonwealth of independent states ${ }^{6}$ and national statistical services $^{7}$. All calculations are available from the authors.

\section{Results}

The ecological situation, social issues and economic growth are considered through the prism of the concept of sustainable development. However, studies (Urbaniec 2016), (Lozowicka 2020), (Medved et al. 2020), (Huan et al. 2019), (Rahma et al. 2019) have shown that at the moment there is no clear relationship between the level of environmental safety and progress towards achieving the economic and social goals of sustainable development.

The developed system of indicators makes it possible to study the anthropogenic impact. Moreover, it shows how the level of socioeconomic development and the standard of living affects ecological safety.

At the first stage, the methodology was tested in the countries of the Eurasian Economic Union. Calculations have shown that throughout the studied period, the EAEU member states demonstrated a stable level of ecological safety. For a more complete understanding of the level of ecological safety in the territory of the post-Soviet space, at the next stage, the EAEU and CIS member states were classified according to the level of ecological safety (Table 1).

Table 1. Classification of the EAEU and CIS member states in terms of ecological safety.

\begin{tabular}{|c|c|c|c|}
\hline Ecological Safety Level & 2010 & 2015 & 2019 \\
\hline $\begin{array}{c}\text { Low } \\
(0.00-0.333)\end{array}$ & $\begin{array}{l}\text { Azerbaidzhan, Armenia, } \\
\text { Kyrgyzstan, Moldova, Tadjikistan, } \\
\text { Uzbekistan, Kazakhstan }\end{array}$ & $\begin{array}{l}\text { Azerbaidzhan, Armenia, } \\
\text { Kazakhstan, Kyrgyzstan, } \\
\text { Moldova, Tadjikistan, Uzbekistan }\end{array}$ & $\begin{array}{c}\text { Armenia, Kyrgyzstan, } \\
\text { Moldova, Uzbekistan, } \\
\text { Tadjikistan, Azerbaidzhan }\end{array}$ \\
\hline $\begin{array}{c}\text { Medium } \\
(0.333-0.667)\end{array}$ & Belarus, Ukraine & Belarus, Ukraine & $\begin{array}{l}\text { Belarus, Ukraine, } \\
\text { Kazakhstan }\end{array}$ \\
\hline $\begin{array}{c}\text { High } \\
(0.667-1.00)\end{array}$ & Russia & Russia & Russia \\
\hline
\end{tabular}

It should be noted that throughout the entire analyzed period from 2010 to 2019, most of the post-Soviet countries have a low level of ecological safety. The level of ecological safety was also assessed for Estonia, as a state that was previously part of the USSR. Although Estonia belongs to countries with a low level of ecological safety (Figure 3), it is characterized by a fairly high level of human development.

In 2010 the integral indicator of ecological safety for Estonia was between low and medium level, but there a gradual deterioration of the indicator is observed.

More information about the trends in the level of ecological safety is given by the grouping of countries, taking into account the dynamics of changes in the integral indicator (Figure 4). Less than $30 \%$ of all considered CIS countries tend to improve their level of ecological safety, and more than $50 \%$ of countries showed a tendency towards a deterioration of the integral indicator. Armenia showed a stable level. 


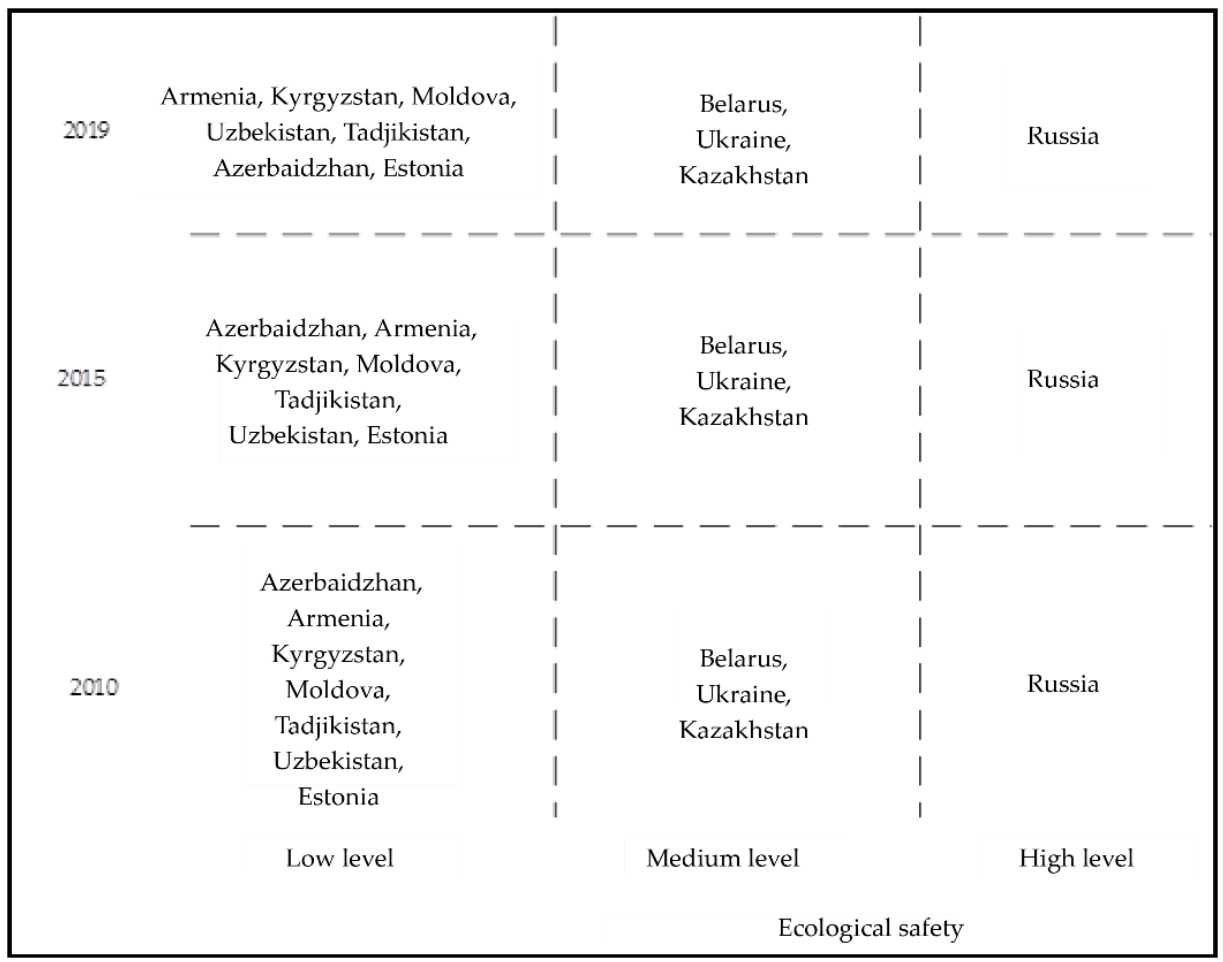

Figure 3. Classification of post-Soviet countries according to the level of ecological safety.

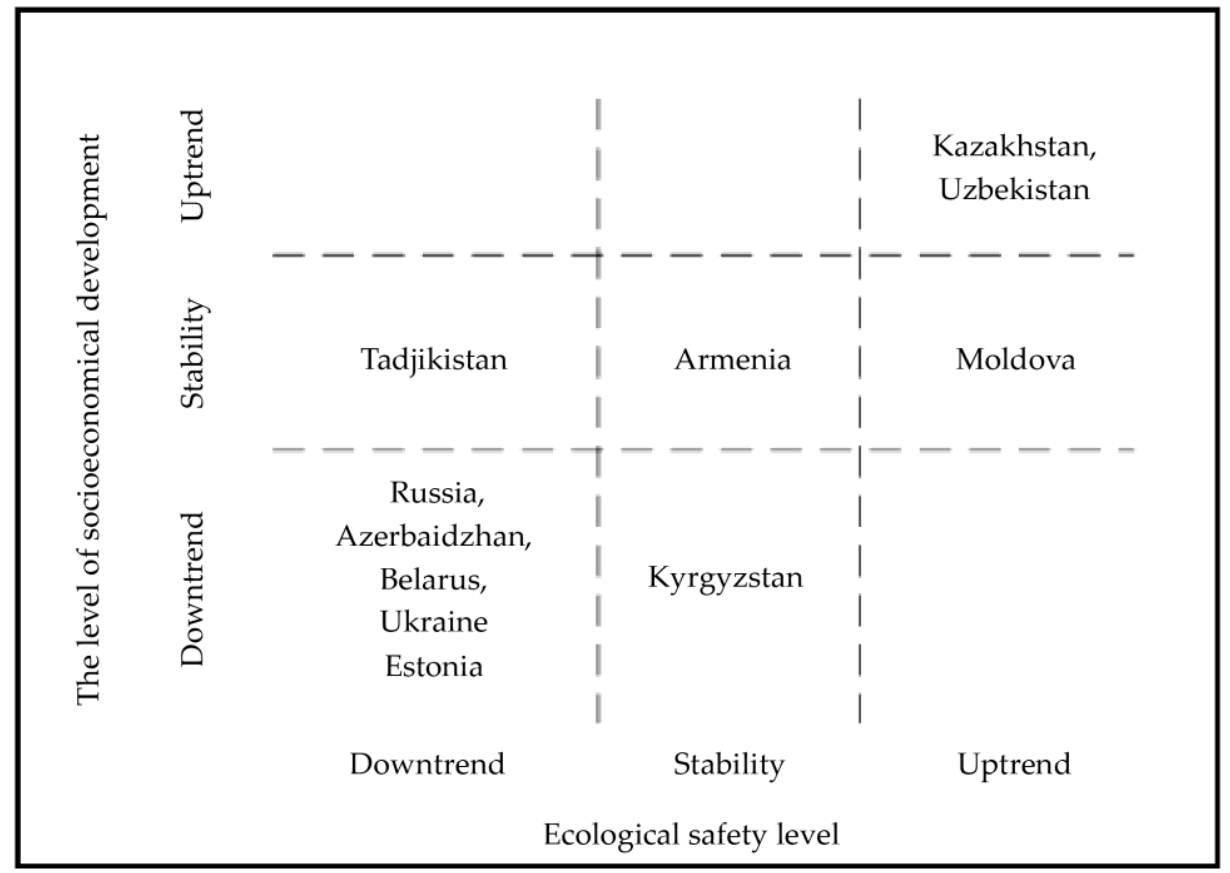

Figure 4. Grouping of the post-Soviet countries taking into account the trends of socioeconomic development.

The role of the country's socioeconomic development in assessing ecological safety is explained by the fact that it affects the environmental component of the integral indicator of ecological safety through the following parameters: total state expenditures on the environment and the volume of investments in fixed assets aimed at environment protection, and at the level of human development (Figure 5). 
- Socio-economic development of the country's territor

Antropogenic impacts on the environment

- Human capital development

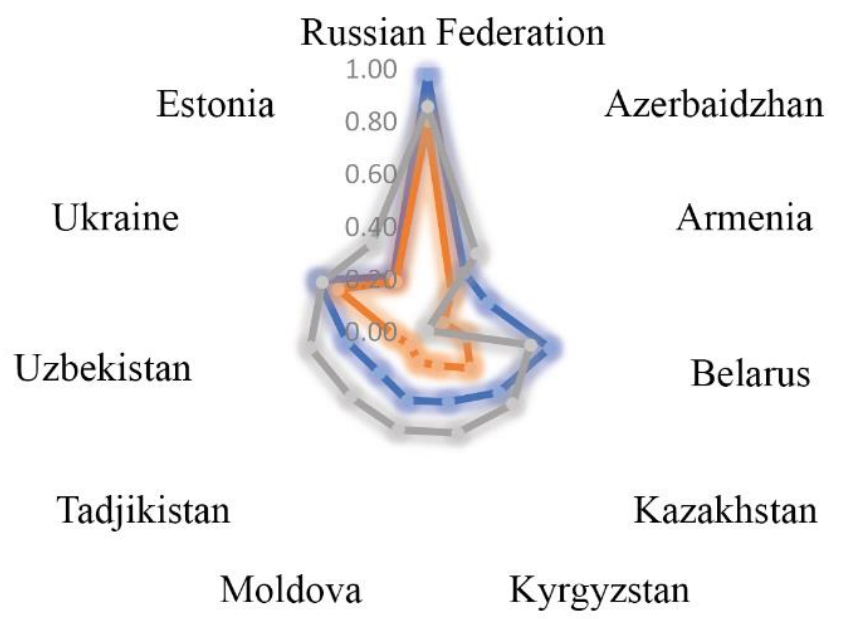

Figure 5. The generalized indicators of socioeconomic, anthropogenic, and human development for post-Soviet countries in 2019.

For $60 \%$ of countries, the downtrend or uptrend of ecological safety occurs against the background of a corresponding change in the socioeconomic development and human capital. The downtrend for ecological safety in Russia, Azerbaidzhan, Belarus, Estonia and Ukraine follows a decline in the level of socioeconomic and human development. The indicated process is reflected in a decrease in the birth rate, a slowdown in the rate of mortality reduction, and a decrease in the rate of industrial production and investment activity. At the same time, a stable socioeconomic situation creates favorable conditions and prerequisites for increasing the level of environmental safety. As shown in Figure 4, Armenia, against the background of a stable level of socioeconomic development, demonstrates the constant value of the integral indicator ecological safety.

Thus, in the EAEU and CIS countries, the improvement of the socioeconomic situation contributes to an increase in the standard of living of the population, an increase in funding for environmental protection measures and investment activity. The described processes affect the progress in achieving sustainable development goals in the field of ecology and human potential.

Consequently, the formed system of indicators allows us to track the contribution of the socioeconomic factor to the ecological safety of the region and the development of its human potential, which subsequently opens up prospects for the development of new and adjustment of existing measures by regulators aimed at achieving the goals of sustainable development of the country.

As was stated above, over the past ten years, Russia has been showing a downward trend in the level of ecological safety. The revealed tendency determines the expediency of assessing the level of ecological safety of the RF regions and their classification. It is interesting to assess Russia since it has unique geographic features. It has an area of $17.08 \mathrm{mln} . \mathrm{km}^{2}$ (first place in the world). Separate regions of Russia are comparable in area with European countries.

\section{Classification of Regions According to the Level of Ecological Safety}

The presented studies have shown that the ecological safety of a particular territory is considered through the prism of indicators characterizing the degree of environmental pollution, the level of morbidity of the population and the cost of restoring the ecosystem. 
Attention was also paid to the relationship between the level of industrial production and anthropogenic impact. The main result, in this case, is the statement of the relationship between the development of industrial production and the level of emissions into the atmosphere, the degree of pollution of water bodies and soils, as well as the growth of diseases caused by these processes.

The performed calculations were used to classify the constituent entities of the Russian Federation according to the level of ecological safety of the regions. It showed that most of the 85 constituent entities belong to the group with a low level of ecological safety: 61 in 2018, 62 in 2014. The medium-level group comprised 19 items in 2018, and 18 in 2014. The high-level group comprised 5 items in 2018, and 5 in 2014 (Appendix B, Figure A2).

However, this information does not allow fully monitoring the main trends in changes that occur within the typological group in terms of the level of ecological safety. For this purpose, a matrix was built, reflecting the main trends (deterioration, stability, improvement) occurring within each group (Figure 6).

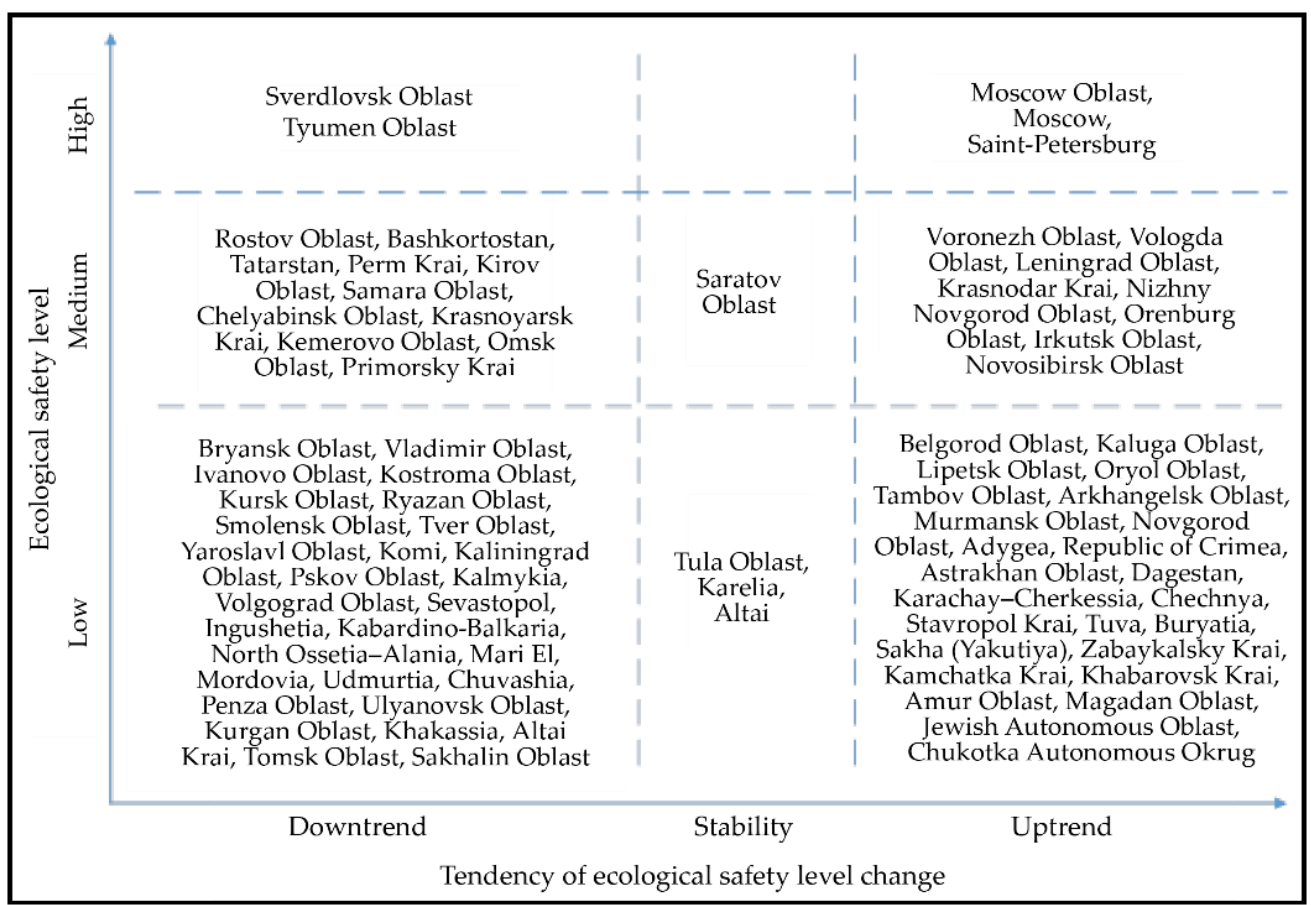

Figure 6. Grouping of subjects of the Russian Federation, taking into account the dynamics of changes in the integral indicator of ecological safety.

Throughout the considered period, three regions (Tula Oblast, Republic of Karelia, Republic of Altai) maintained a stable low level of ecological safety, while one (Saratov Oblast) maintained a stable medium level. $43 \%$ of the RF regions show a tendency towards an improvement in the level of ecological safety, while $52 \%$ of the RF subjects show a tendency towards deterioration.

In most regions, there is a connection between the level of socioeconomic development and an integral indicator of ecological safety. The decline in the level of socioeconomic development was accompanied by a decrease in the level of ecological safety in 31 constituent entities of the Russian Federation. On the contrary, 24 regions demonstrate an increase in the level of ecological safety following an improvement in the level of socioeconomic development. In general, for $67 \%$ of the RF regions, the tendencies of changes in the level of socioeconomic development of the territory determine the dynamics of changes in the level of ecological safety.

For regions with an initially low level of ecological safety, the initially low level of socioeconomic development with a tendency to deterioration was accompanied by a decrease in indicators for 31 constituent entities of the RF (23.5\%), stable indicators for 
2 constituent entities ( $2 \%$ ), improvement in the level of ecological safety for 10 constituent entities (12\%). For regions with an initially medium level of ecological safety, the trends were as follows: deterioration in the level of ecological safety was observed for 4 constituent entities of the RF (5\%), stable indicators for 1 constituent entity $(1 \%)$, improvement for 2 constituent entities ( $2 \%)$.

For regions with an initially low level of ecological safety the initially low level of socioeconomic development with stable characteristics was accompanied by stable indicators for 1 constituent entity of the Russian Federation, improvement in the level of ecological safety was registered for 1 constituent entity of the RF. Initially, the low level of socioeconomic development with a tendency to improve was accompanied by a decrease in indicators for 6 constituent entities of the RF (7\%), an improvement in the level of ecological safety for 17 constituent entities of the Russian Federation (20\%). For regions with an initially medium level of ecological safety, the tendencies are as follows: deterioration of the level of ecological safety for 2 constituent entities of the Russian Federation (2\%), improvement for 5 constituent entities of the Russian Federation (6\%). The results are presented in Figure 7.

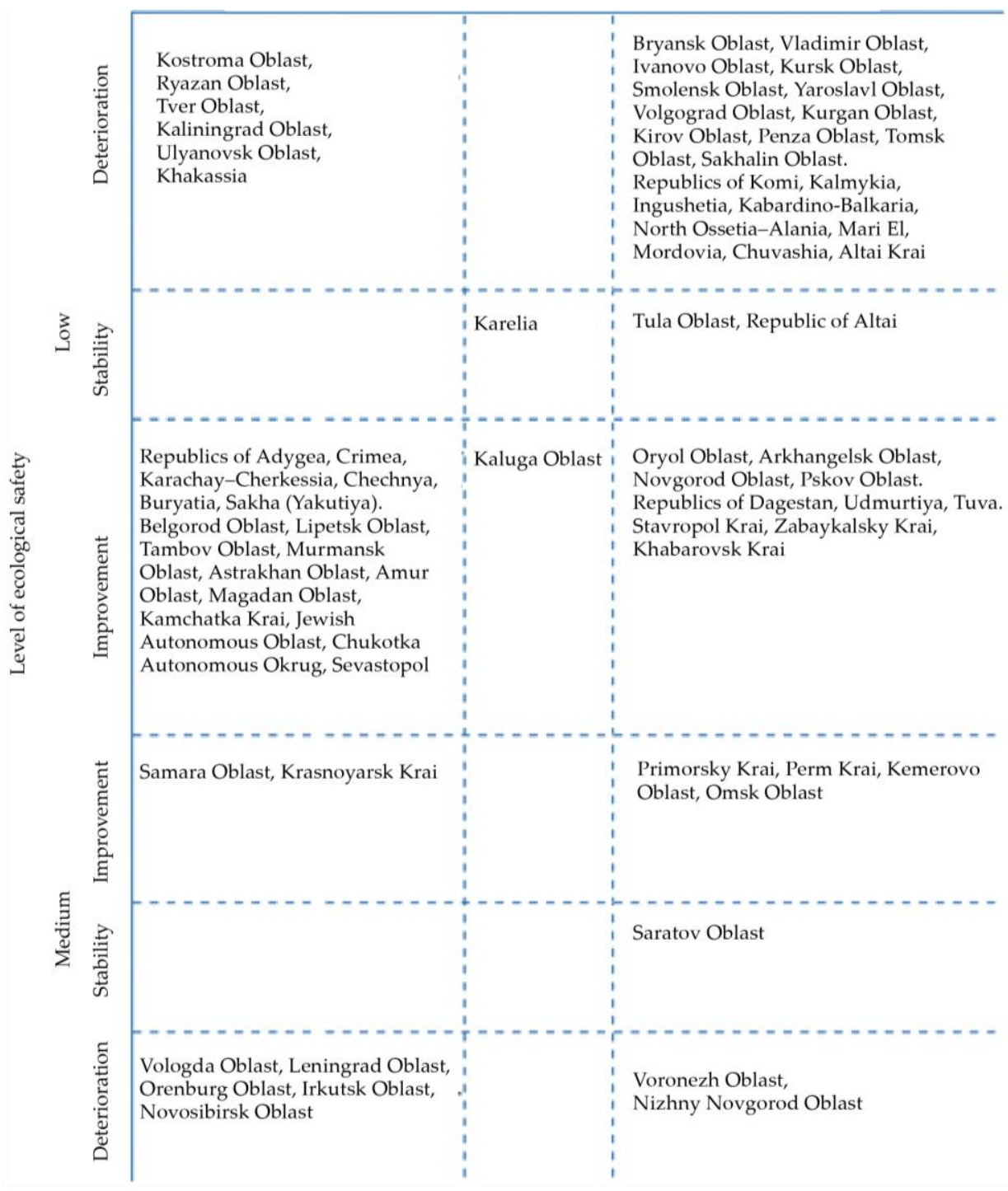

Figure 7. Distribution of the Russian Federation (RF) regions by trends in the level of ecological safety in the group with a low level of socioeconomic development. 
The majority of RF regions show a direct relationship between trends in the change of intermediate generalizing indicators. Thus, the growth in the level of ecological safety of the subject in most cases took place against the background of the growth in the levels of socioeconomic and human development. At the same time, an increase in objects that pollute the environment in several regions is accompanied by a decrease in the volume of polluting emissions into the atmosphere, which occurs against the background of a positive dynamics of investments in fixed assets, an increase in the share of profitable enterprises in the region. The regions with the noted trend are characterized by an increase in housing commissioning, an increase in the birth rate and an increase in children attending preschool institutions, children and youth sports institutions, etc., which, according to the methodology used, indicates the development of the human potential of the region.

\section{Discussion}

This study analyzes natural, social, and economic factors affecting the sustainable development of regions, the core of which is ecological safety. A new conceptual approach was developed, defining ecological safety as an element of the sustainable development concept. The analyzed indicator includes three components, which characterize the socioeconomic development of the territory, the anthropogenic impact on the environment, and the level of human development. A quantitative analysis of the components of ecological safety was carried out for the EAEU and CIS countries and in all (85) Russian regions including time variations. The following conclusions can be drawn:

- Only $30 \%$ of all considered countries tend to improve their level of ecological safety.

- In most countries, improvement or deterioration of the level of ecological safety over a ten-year period occurs against the background of a corresponding change in the socioeconomic component of the integral indicator.

- Over the past ten years, Russia has shown a downtrend in the level of ecological safety, which makes it expedient to assess the level of ecological safety of the regions of the Russian Federation and to classify them.

- $43 \%$ of the RF regions show an uptrend in the level of ecological safety, $52 \%$ of the constituent entities of the Russian Federation show a downtrend.

- The decline in the level of socioeconomic development was accompanied by a decrease in the level of ecological safety in 31 constituent entities of the RF.

- An increase in the level of ecological safety against the background of an improvement in the level of socioeconomic development was shown by 24 regions.

- For $67 \%$ of the RF regions, trends in the level of socioeconomic development of the territory determine the dynamics of changes in the level of ecological safety.

- The tendency to improve both the level of socioeconomic development and the level of ecological safety was noted in 1 constituent entity of the Russian Federation-the Moscow Oblast; the city of Moscow is experiencing a deterioration in the level of socioeconomic development with an improvement in ecological safety indicators.

- For Russia, an acutely relevant solution in practical terms is the transition to a circular economy model.

The results show that most regions have a relationship between the level of socioeconomic development and an integral indicator of ecological safety. Consequently, economic, social, and environmental (a priori) policies can have an impact on the level of ecological safety.

Thus, while considering the issue of ecological safety, the socioeconomic development of the territory should be fully taken into account. Although the level of ecological safety in some regions has improved, only for 5 of 85 regions it is at a high level. This situation can be changed by reorientation of state policy towards the green economy and the formation of a business climate that stimulates the expansion of social responsibility of business, the development of effective forms of public-private partnership. Civil initiatives in the field of disclosing environmental problems and information propaganda on environmental issues should be taken into account. 
However, when using the proposed system of indicators, it is necessary to take into account that a significant part of countries lagging behind in terms of socioeconomic development is characterized by a low level of organization of continuous statistical monitoring and a lack of data in the public domain.

Moreover, the world has a high differentiation of states in terms of area, level of socioeconomic development, endowment with natural resources, natural and climatic conditions. These factors can be taken into account further through the study of the burden of diseases specific to the region, the volume of funding for healthcare activities, and the provision of the country's population with strategically important resources from the standpoint of living standards (fresh water).

The optimal amount of costs and investments in environmental protection measures should be indispensably determined. These costs should contribute to the growth of ecological safety without hindering the sustainable economic development of the territory.

\section{Conclusions}

Sustainable development implies a decrease in the ecological footprint (EF) to the global average of 1.7 gha (Russia exceeds the global average EF, having more than 4 ha per capita) and human development equal to or more than 0.71 (Living Planet Report 2014) . $^{8}$ Demographic growth, modern lifestyles, and human behavior are cited as the top three reasons for environmental degradation as a result of human activities. ${ }^{9}$

In ASEAN countries, environmental pollution has a significant positive impact on R\&D expenditures in both the short- and long-term (Haseeb et al. 2019). Innovation can become a driver of sustainable development if there is a developed scientific and technical infrastructure, a combination of public and private funding, cooperation between research centers and business, as well as the active participation of researchers in international projects (Dul'ová Spišáková et al. 2019). Also, a well-developed innovation culture has a significant beneficial effect on the sustainability of companies (Bilan et al. 2020).

The studied experience of industrialized cities in China has shown that emissions trading can help achieve environmental and economic balance. The greatest efficiency of this tool in achieving sustainable development goals was achieved at a high level of socioeconomic development of the city (Huang et al. 2021). For sustainable urban transport, fuel quality and fuel economy standards, as well as electric two- and three-wheeled vehicles, are prioritized (Bakker et al. 2019).

Brazilian farmers cite subsistence agriculture, investment in innovation and technology, and environmental concerns as the conditions for sustainable agricultural development. However, a lack of information, knowledge, planning, and support are constraining factors (Laurett et al. 2021). The interest of Lithuanian farmers in sustainable agriculture is directly dependent on their environmental competence and economic simulation of participation in green programs (Mierauskas 2020).

In the conditions of openness and digitalization, it seems necessary to make information about the ecological state of territories available to citizens (Cregard and Sobis 2017). Accessibility is ensured by the full coverage and clarity of information, the responsibility should be assumed by government agencies. For example, it can be hardly achieved through the creation of a nationwide information system without changing the environmental policy (Weiss et al. 2017). At the same time, state environmental policy is directly related to the level of public health (Bosworth et al. 2009) and to the prevention of environmental pollution (Ballard et al. 2021). The OECD Regional Well-Being website is an example of an information system. In the frame of this initiative, each of the 1395 regions is measured by categories-income, jobs, housing, health care, access to services, environment, education, safety, civic engagement and governance, community and life satisfaction.

Moreover, the environmental safety of consumers should be ensured. Many buyers consider the labeling of products as environmentally friendly as a sign of their ecological safety, which is not always true. There is a need to improve the labeling policy for green products and educate consumers to understand this issue (Urbański and Haque 2020). 
Another important aspect of the implementation of the concept of sustainable development is the analysis of corporate social responsibility of companies and its compliance with the environmental policy of the region. The level of competence of environmental specialists directly affects the effectiveness of management in the field of sustainable development. It is proposed to rank enterprises by the level of ecological safety based on monitoring their personnel component (Shpak et al. 2019). The greatest effectiveness in increasing the environmental responsibility of employees is achieved through the use of non-financial measures, such as training and prevention of wasteful use of resources (Rafiq et al. 2020). At the same time, efforts to protect the environment are assessed as a prerequisite for increasing the economic efficiency of companies (Caiado et al. 2019). In Russia, mining, manufacturing, electricity, gas and heat supply account for about $84 \%$ of emissions into the environment. The federal project "Clean Air" (national project "Ecology") provides for a $20 \%$ reduction in air pollution in the most polluted cities by 2025 . To achieve this goal, the environmental responsibility of business should be increased, including in terms of the availability and completeness of information. Effective interaction between government institutions and corporations, based on trust and the goal of preserving the environment, can maintain ecological safety in order to achieve sustainable development.

Author Contributions: Conceptualization, S.D. and A.K.; methodology, S.D. and M.B.; software, S.I.; validation, M.B. and S.Z.; formal analysis, M.B.; investigation, T.C., S.D. and M.B.; resources, I.A. and S.Z.; data curation, S.D.; writing—original draft preparation, S.D., M.B. and A.K.; writing-review and editing, S.D., M.B.; visualization, S.D. and T.C.; supervision, I.A. and S.I.; project administration, A.K. All authors have read and agreed to the published version of the manuscript.

Funding: This research received no external funding.

Institutional Review Board Statement: Not applicable.

Informed Consent Statement: Not applicable.

Data Availability Statement: Not applicable.

Conflicts of Interest: The authors declare no conflict of interest.

\section{Appendix A}

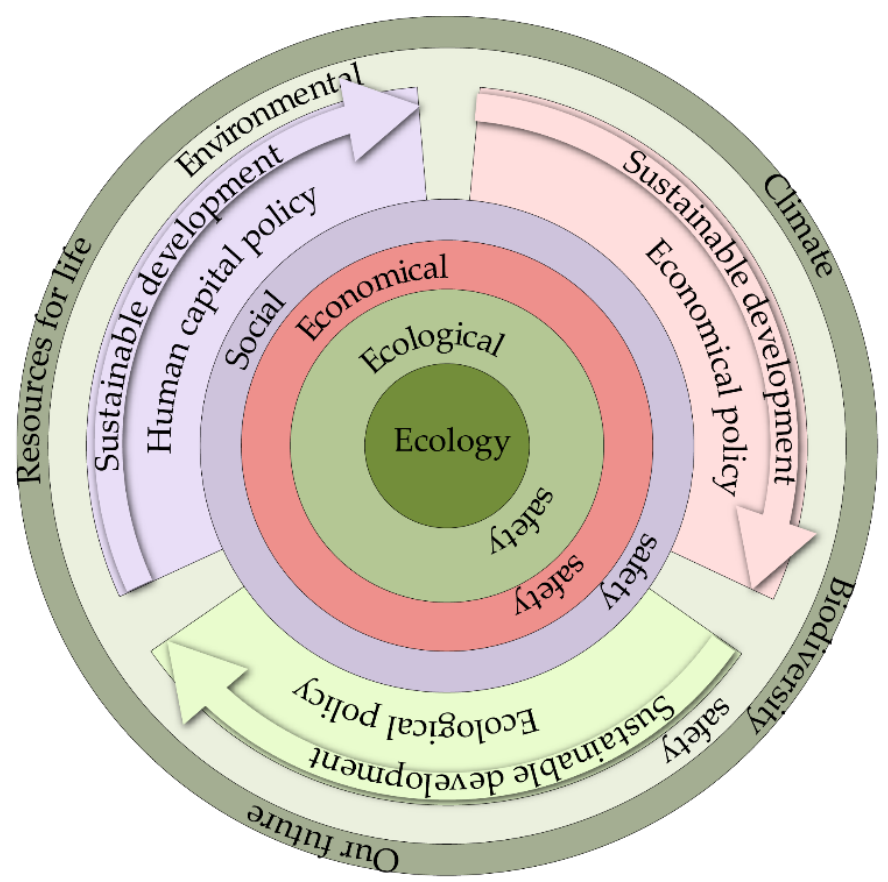

Figure A1. Conceptual model of the relationship between the categories "sustainable development" and "ecological safety". 


\section{Appendix B}

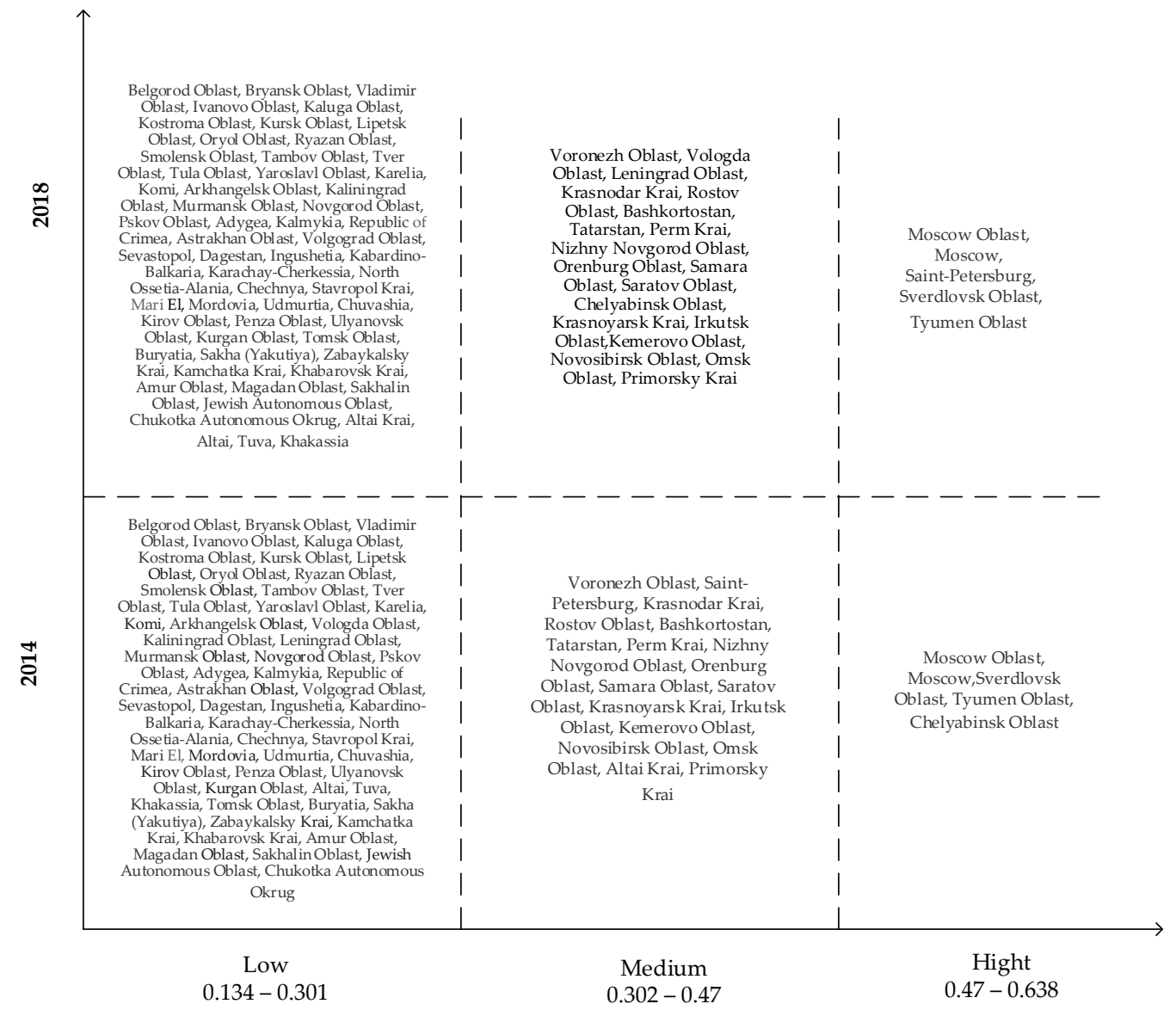

Figure A2. Classification of the constituent entities of the Russian Federation by the level of ecological safety in 2014 and 2018.

\section{Notes}

1 World Commission on Environment and Development. Our Common Future. Oxford University Press: Oxford, UK, 1987. Available online: https:/ / sustainabledevelopment.un.org/content/documents/5987our-common-future.pdf (accessed on 6 January 2021).

Rosleskhoz is reducing the areas where forest fires can be left alone. Rossiyskaya Gazeta 3 November 2020. Available online: https://rg.ru/2020/11/03/reg-urfo/rosleshoz-sokrashchaet-zony-gde-lesnye-pozhary-mozhno-ne-tushit.html (accessed on 6 January 2021).

Novaya klassifikaciya opasnyh proizvodstvennyh ob"ektov [New classification of hazardous production facilities]. Promyshlennaya i ekologicheskaya bezopasnost’ № 3 (77), Mart, 2013. (In Russia).

4 Otchet o rezul'tatah ekspertno-analiticheskogo meropriyatiya «Analiz vypolneniya meropriyatij, obespechivayushchih ekologicheskuyu bezopasnost' Rossijskoj Federacii, v chasti likvidacii ob"ektov nakoplennogo vreda i formirovaniya kompleksnoj sistemy obrashcheniya s tverdymi kommunal'nymi othodami» [Report on the results of the expert-analytical event " Analysis of the implementation of measures to ensure the environmental safety of the Russian Federation, in terms of the elimination of objects of accumulated damage and the formation of a comprehensive system for the management of solid municipal waste»]. Schetnaya Palata Rossijskoj Federacii. 2020. 38 p. (In Russia). Available online: https://ach.gov.ru/upload/iblock/41b/41b02dc50697e6fc5 7ec2f389a8b68f0.pdf (accessed on 7 Marta 2021).

5 Federal State Statistics Service of Russia. Available online: https:/ / rosstat.gov.ru (accessed on 27 December 2020).

6 The interstate statistical committee of the commonwealth of independent states. Available online: http://www.cisstat.com/ index.html (accessed on 20 February 2021).

7 State Statistics Committee of Azerbaijan. Available online: http:/ /www.stat.gov.az (accessed on 20 February 2021); Statistical Committee of the Republic of Armenia. Available online: http:/ / www.armstat.am (accessed on 20 February 2021); National Statistical Committee of the Republic of Belarus Available online: http:/ / www.belstat.gov.by (accessed on 20 February 2021); Bureau of National Statistics of the Agency for Strategic Planning and Reforms of the Republic of Kazakhstan. Available online: 
http:/ /www.stat.gov.kz (accessed on 20 February 2021); National Statistical Committee of the Kyrgyz Republic. Available online: http:/ / www.stat.kg (accessed on 20 February 2021); National Bureau of Statistics of the Republic of Moldova. Available online: http: / / www.statistica.md (accessed on 21 February 2021); Federal State Statistics Service of Russia. Available online: http:/ / www.gks.ru (accessed on 21 February 2021); Agency on Statistics under the President of the Republic of Tajikistan. Available online: http: / www.stat.tj (accessed on 21 February 2021); State Committee of the Republic of Uzbekistan on Statistics. Available online: http:/ / stat.uz (accessed on 21 February 2021); State Statistics Service of Ukraine. Available online: http: //www.ukrstat.gov.ua (accessed on 21 February 2021); Statistics Estonia. Available online: https://www.stat.ee/en (accessed on 25 February 2021).

8 Living Planet Report 2014. Available online: https://wwf.ru/upload/iblock/0f2/lrp_2014_summary_ru_net.pdf (accessed on 6 January 2021).

9 World Education Monitoring Report. Available online: https://gem-report-2016.unesco.org/en/home/ (accessed on 6 January 2021).

\section{References}

Abanina, Elena, Leo Timofeev, Dmitry Agapov, Julia Sorokina, and Anna Ustinova. 2019. Systems of Environmental Security of Urbanized Territories within the Framework of the Program of Ecological Development of Urbanized Territories. IOP Conference Series: Earth and Environmental Science 224: 012031. [CrossRef]

Bakker, Stefan, Gary Haq, Karl Peet, Sudhir Gota, Nikola Medimorec, Alice Yiu, Gail Jennings, and John Rogers. 2019. Low-Carbon Quick Wins: Integrating Short-Term Sustainable Transport Options in Climate Policy in Low-Income Countries. Sustainability 11: 4369. [CrossRef]

Ballard, Parissa J., Melinda Pankratz, Kimberly G. Wagoner, Jennifer Cornacchione Ross, Scott D. Rhodes, Sun-day Azagba, Eunyoung Y. Song, and Mark Wolfson. 2021. Changing course: Supporting a shift to environmental strategies in a state prevention system. Substance Abuse Treatment Prevention and Policy 16: 7. [CrossRef]

Bilan, Yuriy, Hafezali Iqbal Hussain, Muhammad Haseeb, and Sebastian Kot. 2020. Sustainability and economic performance: Role of organizational learning and innovation. Engineering Economics 31: 93-103. [CrossRef]

Bosworth, Ryan C., Cameron Trudy Ann, and DeShazo J.R. 2009. Demand for environmental policies to improve health. Evaluating community-level policy scenarios. Journal of Environmental Economics and Management 57: 293-308. [CrossRef]

Brousmiche, Delphine, Michael Genin, and Florent Occelli. 2021. How can we analyze environmental health resilience and vulnerability? A joint analysis with composite indices applied to the north of France. The Science of the Total Environment 763 : 142983. [CrossRef]

Caiado, Gusmao Rodrigo Goyannes, Osvaldo Luiz Goncalves Quelhas, Daniel Luiz de Mattos Nascimento, Rosley Anholon, and Walter Leal Filho. 2019. Towards sustainability by aligning operational programmes and sustainable performance measures. Production Planning $\mathcal{E}$ Control 30: 413-25. [CrossRef]

Ma, Chun-Chieh, and Hsiao-Ping Chang. 2019. Environmental Consciousness in Local Sustainable Development: A Case Study of the Anti-Idling Policy in Taiwan. Sustainability 11: 4442. [CrossRef]

Cregard, Anna, and Iwona Sobis. 2017. Dissemination of Environmental Information and its Effects on Stakeholders' Decision-Making: A Comparative Study between Swedish and Polish Municipalities. NISP ACEE Journal of Public Administration and Policy. [CrossRef]

Danilov-Danil'yan, Viktor. 2015. Koncepciya ustojchivogo razvitiya: Sushchnost', principy, metodologiya. In Ustojchivoe razvitie: Novye vyzovy. [The concept of sustainable development: Essence, principles, methodology]. In Sustainable Development: New Challenges. Edited by Vladimir Danilov-Danil'yan and Natal'ya Piskulova. Moskva: Aspekt Press, pp. 21-55. (In Russia)

De Buaredon, Kristian. 2017. Ciklicheskaya ekonomika dlya ustojchivogo klimata [A new Cyclical economy for a sustainable climate]. Kommersant 201: 13. (In Russia).

Demidova, Svetlana. 2018. Analiz sostoyaniya ekologicheskoj bezopasnosti v Severo-Zapadnom Federal'nom okruge [Analysis of the state of environmental safety in the North-Western Federal District]. Paper presented at Mnogofaktornye Vyzovy i Riski v Usloviyah Realizacii Strategii Nauchno-Tekhnologicheskogo i Ekonomicheskogo Razvitiya Makroregiona «Severo-Zapad» [Multifactorial Challenges and Risks in the Context of the Implementation of the Strategy of Scientific, Technological and Economic Development of the Macro-Region North-West»], Sankt-Peterburg, Russia, October 23-24; pp. 158-66. (In Russia).

Druzhinin, Pavel, Galina Shkiperova, and Olga Potasheva. 2018. Ekologicheskaya krivaya kuznetsa: Sluchai Rossii i Finlyandii [Environmental Kuznets curve: The case of Russia and Finland]. Ekonomika: Vchera, Segodnya, Zavtra [Economics: Yesterday, Today and Tomorrow] 8: 83-97.

Dul’ová Spišáková, Emília, Barbora Gontkovičová, Janka Majerníková, Emil Spišák, and Andrzej Pacana. 2019. Management of research and development activities in the context of strategy Europe 2020. Polish Journal of Management Studies 19: 112-23. [CrossRef]

Eskelinen, Teppo. 2021. Interpreting the Sustainable Development Goals through the Perspectives of Utopia and Governance. Forum for Development Studies. [CrossRef]

Fuchs, Christian. 2017. Critical Social Theory and Sustainable Development: The Role of Class, Capitalism and Domination in a Dialectical Analysis of Un/Sustainability. Sustainable Development 25: 443-58. [CrossRef] 
Ganebnykh, Elena, Tatyana Burtseva, Petuhova Anastasia, and Mottaeva Angela. 2019. Regional environmental safety assessment. E3S Web of Conferences 91: 08035. [CrossRef]

Glinskiy, Vladimir, Lyudmila Serga, and Khvan Maria. 2014. Ob ocenke urovnya ekologicheskoj bezopasnosti territorij [On estimation of the level of the environmental safety of territories]. Economics, Statistics and Informatics. Vestnik UMO 6: 159-65. (In Russia).

Glinskiy, Vladimir V., Lyudmila K. Serga, and Mariya S. Khvan. 2015. Environmental Safety of the Region: New Approach to Assessment. Procedia CIRP 26: 30-34. [CrossRef]

Gutman, Svetlana, and Anna Teslya. 2018. Environmental safety as an element of single- industry towns' sustainable development in the Arctic region. IOP Conference Series: Earth and Environmental Science 180: 012010. Available online: https://iopscience.iop.org/ article/10.1088/1755-1315/180/1/012010/pdf (accessed on 6 January 2021). [CrossRef]

Haseeb, Muhammad, Sebastian Kot, Hafezali Iqbal Hussain, and Kittisak Jermsittiparsert. 2019. Impact of economic growth, environmental pollution, and energy consumption on health expenditure and R\&D expenditure of ASEAN countries. Energies 12: 3598. [CrossRef]

Hedelin, Beatrice. 2019. Complexity is no excuse: Introduction of a research model for turning sustainable development from theory into practice. Sustainability Science 14: 733-49. [CrossRef]

Hickel, Jason. 2015. It will take 100 years for the world's poorest people to earn $\$ 1.25$ a day. The Guardian. March 30. Available online: https: / / www.theguardian.com/global-development-professionals-network/2015/mar/30/it-will-take-100-years-forthe-worlds-poorest-people-to-earn-125-a-day?CMP=fb_us (accessed on 6 January 2021).

Huan, Yizhong, Haitao Li, and Tao Liang. 2019. A New Method for the Quantitative Assessment of Sustainable Development Goals (SDGs) and a Case Study on Central Asia. Sustainability 11: 3504. [CrossRef]

Huang, Jingru, Jie Shen, and Lu Miao. 2021. Carbon Emissions Trading and Sustainable Development in China: Empirical Analysis Based on the Coupling Coordination Degree Model. International Journal of Environmental Research and Public Health 18: 89. [CrossRef] [PubMed]

Kiselakova, Dana, Malgorzata Stec, Mariola Grzebyk, and Beata Sofrankova. 2020. Multidimensional Evaluation of the Sustainable Development of European Union Countries-An Empirical Study. Journal of Competitiveness 12: 56-73. [CrossRef]

Laurett, Rozelia, Arminda Paco, and Emerson Wagner Mainardes. 2021. Measuring sustainable development, its antecedents, barriers and consequences in agriculture: An exploratory factor analysis. Environmental Development 37: 100583. [CrossRef]

Liu, Yu, Wen Hu, Shanwei Wang, and Lingyun Sun. 2020. Eco-environmental effects of urban expansion in Xinjiang and the corresponding mechanisms. European Journal of Remote Sensing, 1-13. [CrossRef]

Living Planet Report. 2014. Available online: https://wwf.ru/upload/iblock/0f2/lrp_2014_summary_ru_net.pdf (accessed on 6 January 2021).

Long, Liang-jun. 2021. Eco-efficiency and effectiveness evaluation toward sustainable urban development in China: A super-efficiency SBM-DEA with undesirable outputs. Environment Development and Sustainability. [CrossRef]

Lozowicka, Anna. 2020. Evaluation of the Efficiency of Sustainable Development Policy Implementation in Selected EU Member States Using DEA. The Ecological Dimension. Sustainability 12: 435. [CrossRef]

Medved, Primož, Jung In Kim, and Matjaz Ursic. 2020. The urban social sustainability paradigm in Northeast Asia and Europe A comparative study of sustainable urban areas from South Korea, China, Germany and Sweden. International Review for Spatial Planning and Sustainable Development 8: 1-37. [CrossRef]

Mieg, Harald A., and Klaus Töpfer. 2015. Theories of Sustainable Development, rev. ed. London and New York: Routledge, 201p.

Mierauskas, Pranas. 2020. An Overview of Development of Sustainable Agriculture in Lithuania. Paper presented at the 11th International Conference "Environmental Engineering" (11th ICEE), Vilnius, Lithuania, May 21-22. [CrossRef]

Miller, Thaddeus R. 2013. Constructing sustainability science: Emerging perspectives and research trajectories. Sustainability Science 8: 279-93. [CrossRef]

Morozova, Galina Yuryevna, and Irina Dmitrievna Debelaya. 2018. Zelenaya infrastruktura kak faktor obespecheniya ustojchivogo razvitiya Habarovska [Green infrastructure as a factor in ensuring sustainable development of Khabarovsk]. Ekonomika regiona. [Economy of the Region] 2: 562-74. (In Russia). [CrossRef]

Nikulina, Natalia Leonidovna. 2014. Problemy ocenki ekologicheskoj bezopasnosti regiona [Problems of the estimation of ecological safety of region]. Ekonomika regiona. [Economy of the Region] 4: 62-67. (In Russia).

Pahomova, Nadezda V., Knut K. Rihter, and Mariya A. Vetrova. 2017. Perekhod k cirkulyarnoj ekonomike i zamknutym cepyam postavok kak faktor ustojchivogo razvitiya [The transition to a circular economy and closed supply chains as a factor of sustainable development]. Vestnik Sankt-Peterburgskogo Universiteta 33: 244-68. (In Russia). [CrossRef]

Pisarenko, Pavel, Marina Sergeevna Samojlik, Irina Leonidovna Plaksienko, and Larisa Anatolievna Kolesnikova. 2019. Konceptual'nye osnovy obespecheniya resursno-ekologicheskoj bezopasnosti v regione. Teoreticheskaya i Prikladnaya Ekologi 2: 137-42.

Polyanskaya, Irina, and Vera Yurak. 2017. Institutional assessment of environmentally oriented subsurface use [Institucional'naya ocenka ekologicheski orientirovannogo nedropol'zovaniya]. Ekonomika regiona. [Economy of the Region] 13: 355-68.

Purohit, Pallav, Markus Amann, Gregor Kiesewetter, Peter Rafaj, Vaibhav Chaturvedi, Hem H. Dholakia, Poonam Nagar Koti, Zbignev Klimont, Jens Borken-Kleefeld, Adriana Gomez-Sanabria, and et al. 2019. Mitigation pathways towards national ambient air quality standards in India. Environment International 133, Pt A: 105147. [CrossRef] 
Rafiq, Muhammad, XingPing Zhang, Jiahai Yuan, Shumaila Naz, and Saif Maqbool. 2020. Impact of a Balanced Scorecard as a Strategic Management System Tool to Improve Sustainable Development: Measuring the Mediation of Organizational Performance through PLS-Smart. Sustainability 12: 1365. [CrossRef]

Rahma, Hania, Akhmad Fauzi, Bambang Juanda, and Bambang Widjojanto. 2019. Development of a Composite Measure of Regional Sustainable Development in Indonesia. Sustainability 11: 5861. [CrossRef]

Ricardo, Mario Arturo. 2021. The 2030 Agenda for Sustainable Development in the United Nations Context. Knowledge Management and Ciencias Administrativas 17: 79-84. [CrossRef]

Rodnyansky, Dmitry, Vadim Kovrigin, Ivan Makarov, Sergey Manasyan, and Olga Shirokova. 2020. The Efficiency Assessment of State Environmental Safety in Russian Industrial Regions Proceedings of the Research Technologies of Pandemic Coronavirus Impact (RTCOV 2020). Advances in Social Science. Education and Humanities Research 486: 1-6.

Shi, Longyu, Linwei Han, Fengmei Yang, and Lijie Gao. 2019. The Evolution of Sustainable Development Theory: Types, Goals, and Research Prospects. Sustainability 11: 7158. [CrossRef]

Shpak, Nestor, Zoriana Dvulit, Liana Maznyk, Oksana Mykytiuk, and Włodzimierz Sroka. 2019. Validation of ecologists in enterprise mamnagement system: A case study analysis. Polish Journal of Management Studies 19: 376-90. [CrossRef]

Skene, Keith R. 2020. No goal is an island: The implications of systems theory for the Sustainable Development Goal. Environment, Development and Sustainability. [CrossRef] [PubMed]

Sugak, Evgeniy. 2019. Sustainable development and social and environmental risks of industrial regions of Siberia. IOP Conf. Series: Earth and Environmental Science 395: 012093. [CrossRef]

Urbaniec, Maria. 2016. Measuring and Monitoring Effects of Sustainable Development in the European Union. European Journal of Sustainable Development 5: 1-17. [CrossRef]

Urbański, Mariusz, and Adnan ul Haque. 2020. Are you environmentally conscious enough to differentiate between greenwashed and sustainable items? A global consumers perspective. Sustainability 12: 1786. [CrossRef]

Vahrushev, P. A. 2015. Ekologicheskij inzhiniring kak effektivnyj sposob obespecheniya ekologicheskoj bezopasnosti predpriyatiya [Environmental engineering as an effective way to ensure the environmental safety of the enterprise]. Promyshlennaya Ekologicheskaya Bezopasnost' 7: 48-52. (In Russia).

Weiss, Joseph S., Dajian Zhu, Maria Amélia Enríquez, Peter H. May, Elimar Nascimento, Walter Alberto Pengue, and Stanislav Shmelev. 2017. UN environmental policy: Non-State Actors, trends, and the regulatory role of the state. Journal of Political Ecology. 24. Available online: https://journals.uair.arizona.edu/index.php/JPE/article/view/20980 (accessed on 6 January 2021).

Wendling, Zachary, John W. Emerson, Alex de Scherbinin, and Daniel C. Esti. 2020. Environmental Performance Index 2020. New Haven: Yale Center for Environmental Law and Policy [Electronic Resource], Available online: https: / / epi.yale.edu (accessed on 6 January 2021).

World Commission on Environment and Development. 1987. Our Common Future. Oxford, UK: Oxford University Press, Available online: https: / / sustainabledevelopment.un.org/content/documents/5987our-common-future.pdf (accessed on 6 January 2021).

Zhang, Chi, Wenhui Kuang, Jianguo Wu, Jiyuan Lia, and Hangin Tian. 2021. Industrial land expansion in rural China threatens environmental securities. Frontiers of Environmental Science E Engineering 15: 29. [CrossRef] 